Research Report No. 28/2012

\title{
Making Bricks Without Straw: The Creation of a Transnational Labour Regime
}

Harry W. Arthurs

Osgoode Hall Law School of York University, harthurs@osgoode.yorku.ca

Follow this and additional works at: http:// digitalcommons.osgoode.yorku.ca/clpe

\section{Recommended Citation}

Arthurs, Harry W., "Making Bricks Without Straw: The Creation of a Transnational Labour Regime" (2012). Comparative Research in Law \& Political Economy. Research Paper No. 28/2012.

http://digitalcommons.osgoode.yorku.ca/clpe/23 


\section{OSGOODE}

\section{OSGOODE HALL LAW SCHOOL}

Comparative Research in Law \& Political Economy

RESEARCH PAPER SERIES

Research Paper No. 28/2012

\section{Making Bricks Without Straw: The Creation of a Transnational Labour Regime}

H.W. Arthurs

Editors:

Peer Zumbansen (Osgoode Hall Law School, Toronto, Director, Comparative Research in Law and Political Economy)

John W. Cioffi (University of California at Riverside)

Leeanne Footman (Osgoode Hall Law School, Toronto, Production Editor)

Comparative Research in Law \& Political Economy 
Osgoode CLPE Research Paper 28/2012

Vol. 08 No. 06 (2012)

\title{
H.W. Arthurs
}

\section{Making Bricks Without Straw: The Creation of a Transnational Labour Regime}

\author{
Global Governance: Critical Legal Perspectives \\ A conference in honour of David Trubek \\ European University Institute, Fiesole \\ June 2012
}

\begin{abstract}
This essay suggest that attempts to create a transnational regime of labour regulation have been frustrated by a series of related and mutually reinforcing developments: the incapacity or unwillingness of states to intervene in labour markets; changes in those markets associated with globalization and post-industrial capitalism; the decline of the "standard employment contract"; the demise of working class consciousness, solidarity and power; and the shift from "hard" to "soft" labour law. It concludes with a proposal for three-part strategy of reinventing labour law in the new dispensation: by enlarging its intellectual ambition; expanding its clientele; and extending its spatial reach.
\end{abstract}




\section{PART I: INTRODUCTION}

David Trubek, amongst his other improbable endeavours, has been showing us how we might construct a regime of transnational labour regulation. This, one might say, is "like making bricks without straw". Of course, the analogy is one commonly used to describe any task that is impossibly difficult, but it also happens to be particularly relevant to the themes of this conference. Recall the origins of the phrase. In one of history's earliest recorded labour disputes, the Israelites - a community of undocumented migrant workers - petitioned on religious grounds for a three day respite from their work at the Pharaonic brickworks. Pharaoh took umbrage, and ordered the Israelites to maintain production. Moreover, to discourage future impertinences, he refused to provide them with straw, the binding agent that holds mud bricks together. Instead, he decreed, the Israelites had to provide their own straw, which was very hard to come by locally and had to be sourced through an extended supply chain. Pharaoh's unfair labour practices in turn provoked the world's first general strike, the Exodus.

The outcome of this dispute is instructive for our purposes: denied their rights under national law, the Israelites managed to persuade a supranational agency — located, like the ILO, on a hilltop - to proclaim the six day work week as a core labour right. This ought to have been an inspiring, if not controlling, precedent for efforts today to construct a transnational regime of labour regulation. However, the prospects for such a regime are not bright. Most of its constituent elements are degraded or defunct. The Pharaoh is long gone: globalization has radically impaired the nation state's willingness and ability to regulate labour markets. There is of course no readily available straw: we have long since 
ceased to expect that materials will be sourced anywhere near where things are produced or consumed. Moreover, fewer bricks are being made these days, at least in the developed economies where wealth is most often generated not by control over physical processes or corporeal products, but rather by ownership of intellectual property, intangible goodwill and itinerant capital. And most seriously, there are no more Israelites: no working class, no solidarity, no mass mobilization, no burning bush of socialism or syndicalism, no new Jerusalem under construction or on the drawing boards.

The consequences are easily observed. Few stone tablets - few hard laws to protect workers - descend these days from Mt Sinai or Geneva, or indeed from Westminster or Washington: only soft, law-like codes of conduct or international conventions with vague admonitory norms like "freedom of association" and "decent work". Worse yet, due to the widespread decommissioning or disregard of regimes of labour market regulation, where hard labour law still exists it is often un-enforced - just like the $4^{\text {th }}$ commandment to cease work on the Sabbath.

In succeeding sections of this essay, I will move first from analogy to critique, and then from critique to prophecy.

\section{PART II: FROM ANALOGY TO CRITIQUE}

Pharaoh's decline and fall: the unwillingness and/or incapacity of nation states to regulate 
The postwar period — the "golden age" of labour market regulation in the advanced economies - was an era in which the state ruled in Pharaoh-like fashion. The spread of collective bargaining, the enhancement of labour standards, the expansion of the social safety net, the growth of consultative, corporatist or tripartite institutions: all of these were the work of national governments, usually acting in close collaboration with the social partners. From 1945 to, say, the 1970s, most governments adhered to social democratic or social market policies, either because they believed in them or because it was expedient to act as if they did. Their collaboration with the social partners in protecting the rights and interests of workers was sometimes voluntary, sometimes coerced, but almost always sufficiently sustained and multifaceted to maintain everyone's commitment to what became known as "the postwar compromise" or "welfare capitalism". Of course, labour market regulation was only one part of that compromise, of that form of capitalism. Another key element was the provision of extensive public goods and services. And a third was the development of effective and reciprocating institutions of private and public governance designed to coordinate and reinforce the whole arrangement.

Obviously, welfare capitalism took many forms reflecting the alignment of political forces and the economic profile of different countries. America was not Italy was not Sweden. Nonetheless, each of these countries - and all the other advanced economies - adopted its own national version of the postwar compromise. In this sense, labour law was indisputably national law. Indeed, it was so "national" in character that labour law was the case-in-point most often cited to prove that the "transplantation" of legal systems, even from one advanced economy to another, was doomed to failure. 
This is not to deny that ideas about labour market regulation — like goods, capital, technology and people - moved from country to country during the postwar period. But "globalization" as we know it was in its early stages of development. That is to say, we had not yet experienced the hegemony of market fundamentalism, the triumph of monetarism, the populist revolt against taxation and government spending, the functional and legal integration of regional economies, the new international division of labour and the ubiquity of transnational value chains all of which have, since the 1970s, helped to undermine national systems of labour market regulation. Over the past thirty or forty years, however, things have changed considerably. While national governments retain considerable formal power to regulate, and occasionally exercise it, in general they do so against their principles and at their peril. To provide workers with access to decent pensions, health care or unemployment benefits is to risk the wrath of central bankers and bond-rating agencies. To effectively protect workers' rights to unionize, strike and exercise collective voice is to remind employers of their right to relocate to some other, less foolhardy, jurisdiction. To talk the language of solidarity, inclusion and compassion is to provoke political responses that range alphabetically from amusement to xenophobia none of them responses governments want to provoke. In short, national governments the Pharaohs of the postwar era - have either ceased to believe in progressive labour policies or have become afraid to implement them. 
Now to translate analogy into critique: national systems of labour regulation may be designed to reinforce (or transform) the larger political economy; they may reflect (or seek to revise) historical and sociological imperatives; they may be shaped by (or constitute a reproach to) constitutional norms and legal cultures. They are therefore deeply embedded in the congeries of regulatory systems which we usually call "the state". In conjuring up the prospect of a transnational system of labour market regulation, however, we are imagining what that system would look like "without the state".

\section{Neither bricks nor straw: employment and employment regulation under post-industrial capitalism}

Systems of labour market regulation are not merely embedded in states: they are lodged in the interstices of technological and social systems. In the first four decades of the $20^{\text {th }}$ century, "scientific" innovations in management and manufacturing methods achieved such significant improvements in productivity in countries as different as the United States, the Soviet Union and Germany that might even have impressed Pharaoh (some of whose coercive strategies they enthusiastically emulated). In the capitalist democracies at least, these achievements laid the groundwork for postwar labour policy, in three respects. First, productivity gains were often achieved via internal labour markets which in turn gave rise to what came to be called the "standard employment contract". This "contract" - as much social practice as legal institution - provided workers with decent wages, benefits and the prospect (if not necessarily the enforceable promise) of long-term employment. Second, the "standard employment contract" influenced the design, funding and delivery of public policies dealing with unemployment benefits, retirement income security, health care, skills training and industrial relations. And third, relative stability in labour markets 
based on the standard employment contract allowed workers to unionize, acquire purchasing power, become consumers and embrace welfare capitalism, rather than more radical solutions to the "social question".

Moreover, the standard employment contract was particularly well-suited to an era when most advanced economies were engaged in postwar reconstruction, when they were making good longstanding deficits in infrastructure and capital goods, when wartime production methods were being adapted to meet pent-up consumer demand, and when Keynesian policies helped to sustain the momentum of postwar expansion and prosperity. But what technology, consumption and public policy hath wrought, they could wreck as well — and ultimately did. Accelerating technological change allowed employers to replace semi-skilled workers with robots or send work to non-union feeder plants locally or in other countries; hyper-consumption led to excessive personal debt; and three or four decades of welfare capitalism ultimately produced its neo-liberal antithesis, in the form of resistance to high levels of taxation, state expenditure and market regulation.

Conceding that a broad brush is not ideal for etching in fine details, the point is this: Mass production manufacturing was the engine that drove postwar prosperity; it was the home of large numbers of unionized workers and centre-left voters; and it provided the paradigm of the standard employment relationship that informed much postwar labour and social welfare legislation. Consequently, the decline of mass production manufacturing in OECD countries radically altered the landscape. The loss of their core 
membership of industrial workers had devastating effects on national union movements and weakened centre-left political parties. The decline of manufacturing also put in question the relevance and viability of laws and institutions designed to regulate the labour markets of industrial economies. And the loss of well-paying manufacturing jobs undermined the ability of many advanced economies to sustain consumer demand, tax revenues, public expenditure and, therefore, the whole postwar compromise.

What lesson should be learned from the demise of the brickworks of industrialized nations? Without bricks or straw, I contend — without manufacturing or its equivalent no system of regulation is likely to produce social outcomes comparable to those achieved by the advanced economies during the postwar period.

However, it is unlikely that manufacturing in the industrialized west can be resuscitated, especially in an era of global free trade; and it is improbable that large numbers of displaced skilled or semi-skilled industrial workers will soon find well paid, secure jobs in some other sector. Or to frame the same thought a little more constructively: the success of any transnational system of labour regulation depends on the development of effective transnational strategies to correct the structural weaknesses besetting the advanced economies.

\section{The mysterious disappearance of Israelites: the demise of working class consciousness,} identity, solidarity and power

The departure of the Israelites from Pharaoh's brick works was not just a strike to secure improved working conditions. It was ultimately an act of solidarity and resistance in which 
economically subordinate and politically disenfranchised people challenged the values and institutions of the society in which they lived and worked. Strikes have always had this dual character: on the one hand, their immediate aim is to threaten or impose economic harm on particular employers in order to win improved wages and working conditions; on the other, their ultimate effect is sometimes to remind ruling elites of the potential of working-class mobilization to radically revise the social order itself.

Of course, conventional strikes have become a rarity in the United States, and most other countries. And working class mobilization, whether at the barricades or the ballot box, is rarer yet. Although unions have helped to organize anti-globalization, anti-finance capital, and anti-austerity demonstrations in many countries, many union members vote for political parties that favour globalization, finance capital and austerity. It is not just that employers hold the trump cards when unemployment is high and jobs can be exported pretty much at will; it is not just that legal protections for collective labour action have been repealed or become decrepit; and it is not just that employers and right-wing governments have repudiated the postwar social contract. It is that the decline in working class consciousness, identity, solidarity and power have made these things possible.

That decline represents the most fundamental challenge imaginable to labour law. The very concept of "labour" - whether as a movement, as a sociological descriptor, as a factor of production or as a domain of public policy and intellectual inquiry - depends on some commonality amongst all those included in the category. That commonality has long since 
disappeared. Though much of what they used to do is now done by machines, people still work. But they work differently: work that once required close cooperation amongst proximate operatives is now spread around the world; working class bonds that once were reinforced by ties of gender, race, ethnicity, religion or culture have been loosened by the increasing heterogeneity of the workforce; and dreams of "full employment", promulgated by postwar governments, and of "decent work", sanctified by the ILO, have given way to the reality of a polarized knowledge economy comprising "good jobs" and "bad jobs", "standard" jobs and "precarious" jobs.

These changes in the nature of work, workplaces and workers have radically challenged the notion that all workers ultimately have common interests. Indeed, workers are now arguably more likely to identify with each other on the basis of their role as consumers rather than producers. What brand of beer they drink, what football team they support, what religious sect they adhere to, what ethnic or national myth they align themselves with: all of these seem more accurately to express their aspirations and more effectively to mobilize their energies than solidarity with fellow workers determined to vindicate their rights and interests through industrial or political action.

As dramatic as is the decline of labour solidarity at the national level, it is even more so at the global level. Workers scattered along the now-ubiquitous global value chains not only often lack the prerequisites for solidarity — common experiences, values, rights; they can seldom even identify their common corporate adversary. And worse yet: they are effectively in competition with each other for available work. "Workers of the world unite" 
was a stirring call to action when it was first pronounced in 1848; but few answered the call then and fewer still would do so today. Nor are there martyrs to inspire them: no little children dying in dark satanic mills, no heroic workers sabred at Peterloo, or shot on the Paris barricades. Nor, most importantly, is there a Manifesto, a blueprint for a better future that might rally workers to seize control of their own fate or, more prosaically, to vote or strike in their own long-term economic interests. Nonetheless, transnational solidarity will arrive — if it ever does — only when "hard working" "middle class" "home owning" men and women who have lost their jobs and savings, their dignity and hopes, come to perceive that they share their predicament with people around the world, and that their best prospects lie in seeking solidarity for constructive action at all levels - locally, nationally and across traditional state and class boundaries. Some of these people have sought solace in the Tea Party or the Front National. Some have joined the Indignants in Syntagma Square or the Occupy Wall Street movement in Zuccotti Park. But many perhaps most - remain too confused or dispirited to manifest solidarity in any form or venue.

To return to my analogy: there are no more Israelites.

\section{Soft law from Sinai: the end of "hard" labour law?}

The commandments handed down on Sinai were hard law, literally chiselled in stone: immutable, clear and meant to be enforced by severe sanctions. Those handed down by 
national and transnational governments are increasingly "soft". While the situation varies from country to country, and across the electoral cycle, it is broadly true to say that "hard" labour law plays a much-reduced role today in the regulation of most labour markets and workplace relations. Take the United States: the core provisions of the National Labor Relations Act have never been updated since the law was enacted in 1935; the collective bargaining system it was meant to nurture has virtually ceased to operate; and the NLRB that administers the Act almost had to suspend operations earlier this year for want of a quorum. Other hard laws - forbidding workplace discrimination and harassment or guaranteeing minimum standards - have been "softened" by judicial rulings that allow employee complaints to be diverted from independent courts and tribunals to private arbitrators appointed by their employer. Recent decisions creating exceptions to the egregious doctrine of at-will employment, are likely to provide "softer" recourse for impecunious rank-and-file workers, who cannot afford to litigate, than for privileged executives and professionals who can. And "soft" internal complaints procedures, established by employers as part of their so-called "total HR management" strategy, are becoming increasingly commonplace.

Admittedly, America is the extreme case amongst the advanced economies. In the UK and Australia, for example, a degree of hard-law protection for workers was restored by Labour governments following the anti-union onslaughts of their conservative predecessors. In many European countries, the hard law inscribed in postwar constitutions, legislation and jurisprudence has survived, albeit increasingly in diminished form. And the EU itself has adopted a number of hard-law requirements relating to 
corporate governance, information-sharing, workplace discrimination and other matters, while rulings of the European Court of Justice and the European Court of Human Rights have had a direct, if limited, effect on the legal rules governing employment relations. That said, however, hard labour law is in decline even in Europe.

By contrast, soft labour law has become more commonplace: broad declarations of high principle contained in international treaties, conventions or compacts; codes of practice announced unilaterally by employers or adopted under public pressure or compulsion of law; unenforceable "endorsements" or "affirmations" of labour rights pasted like fig leaves over the awkward bits of regional trade or development schemes; "enlightened" HR practices announced by employers to forestall unionization, escape regulatory scrutiny, improve employee recruitment, enhance productivity, win awards or placate critics.

However, there are good reasons to be wary of soft law. It lacks the democratic legitimacy that comes with legislative enactment; it cannot command the coercive power of the state; it is often couched in general, even anodyne, language that leaves considerable room for "interpretation" by reluctant employers or timid administrators; and it generally positions workers as passive beneficiaries rather than active architects of workplace normativity. On the other hand, perhaps the shift from hard to soft labour law is part of a general trend away from sclerotic "command and control" models of regulation to more supple, "decentred" systems. This general trend proceeds from several premises: that the regulatory state promised more than it could deliver; that hard law sometimes 
produced unintended, even perverse, results; and that soft law, especially in its reflexive variant, has the opportunity to operate more efficiently and effectively than hard law. These critiques of hard law are telling; but whether soft law will in fact provide workers with more protection or less remains an open question.

Or perhaps the displacement of state-promulgated labour law by non-state forms of labour market regulation reflects broader tendencies towards a globalized economy, whose institutions of trans-national governance characteristically (some would say intentionally) generate soft rather than hard law. Or perhaps what appears to be a trend to soft law is no more than the current manifestation of labour law's historic oscillation between state and non-state forms of regulation, in the course of which legislation and markets, power and fairness, explicit and implicit normativity reinforce, subvert and reshape each other. Or perhaps one should simply acknowledge that given the labour movement's current and longstanding weakness, the choice may not be between hard law and soft law modes of regulation, but between soft law and none at all. Whatever the cause of the decline of hard law and the turn to soft law, the crucial question is surely whether this development has left workers better or worse off. By almost any measure - access to jobs and job tenure; prospects for maintaining or improving wages, benefits and working conditions; income security in the event of redundancy, illness, pregnancy or retirement; voice in corporate decision-making; influence over public policy - one would have to say that the situation of workers in the advanced economies has in many respects deteriorated rather than improved over the past twenty or thirty years. At the same time, and with extensive caveats, it would be fair to say that measured by the 
same metrics, conditions for workers in many developing economies have improved during the same period, and that that the turn to soft law as the characteristic mode of regulation in the global economy may have contributed modestly to that improvement.

\section{PART III: FROM CRITIQUE TO PROPHECY: THE PROSPECTS FOR TRANSNATIONAL LABOUR REGULATION “AFTER LABOUR”}

National regimes of labour law and regulation confront an existential question: what will they become now that their intended beneficiaries and traditional proponents appear no longer to regard themselves as "labour"? One response to that question is to restate labour rights as broad political, social and human rights and to entrench them in national constitutions. That solution is unlikely to do much to protect workers. Constitutions tend to reflect and reinforce values that are already deeply ingrained in a society, to define power relations rather than transform them. A second is to entrench labour rights in the supra-national equivalent of national constitutions - in the charters, covenants and conventions that form part of the universal law of nations or the fundamental law of the UN, the EU and similar organizations. For reasons outlined above, I regard this approach as equally unpromising. It is not that I attach no value to domestic or transnational entrenchment of labour rights. Rather, I regard these two responses as solutions to the wrong problem. The labour movement and its constituents are in dire straits not primarily because of deficiencies in the provenance, form, content or administration of labour laws, but because "labour" is no longer a social force to be reckoned with or 
(increasingly) even an concept with a social referent. If this is true, my over-taxed Exodus analogy may point towards a different future for labour law.

According to the plain language or fundamentalist reading of the bargain on Mt. Sinai, in exchange for agreeing to observe the Ten Commandments, the Israelites were promised land and all the milk and honey appertaining thereto. This particularist interpretation of events on Mt. Sinai valorizes national or religious "identity", in much the same way that labour law does class membership or the employment relation. But there is another - a prophetic or universalist - interpretation. The Israelite narrative (and the narrative of employment) can be understood as a specific instance of injustice that reinforces the case for adherence to a general principle: everyone is entitled to freedom, dignity and a decent life; everyone should be treated with fairness and compassion. The ultimate value, in this prophetic interpretation, is social justice, not identity.

In the spirit of this second interpretation of the Exodus, I pose a few simple but fundamental questions:

- why should labour lawyers not treat the plight of workers as a special instance of a general problem: the problem of controlling super-ordinate economic power?

- why should we have one set of legal rules and institutions for workers employed under standard employment contracts, and a plethora of others - often less extensive and efficacious - for contingent or autonomous workers, farmers or tenants, mortgagors or the operators of small, franchised businesses? 
- and why, for that matter, should the law be build around recognition of the specificity of categories such as employment, race, gender or disability rather than acknowledgement of the reality that economic subordination cuts across all of these categories and causes most of the afflictions suffered by the people who populate them?

These suggestions lead to a proposal that is at least worth considering: if national labour law has, sadly, reached a cul de sac, perhaps the best way to extricate it is to enlarge its intellectual ambition, clientele and spatial reach.

Intellectual ambition first. Perhaps it is time for labour lawyers to stop tinkering with the machinery of labour market regulation and tweaking the rules of workplace relations. Perhaps they should devote more time and energy to finding ways to locate labour issues within a larger critique of the particular predatory form of capitalism that seems to have gained ascendancy in some advanced economies. Everyone — not just "labour" — has a stake in labour law's intellectual realignment. Take the issue of deregulation, for example: the deregulation of financial markets has generated as much grief for ordinary citizens including but not limited to workers - as deregulation of labour markets. Take the decline of social security systems in many countries: the loss of access to health care, social housing and decent pensions affects everyone, not just the vestigial remnant of the union movement. Or take intergenerational equity: the growth of economic inequality and insecurity - both closely linked to the demise of collective bargaining - impairs the life 
chances of future generations as profoundly as degradation of the environment or the growth of personal and national indebtedness.

In other words, we might begin to think of labour law as one branch of the "law of economic subordination and resistance".

Seen in this way, labour law would not only be linked to larger and more lively domains of contention; it would address a new and broader clientele. It would concern itself with fairness not just for workers, but for farmers, small business owners and tenants as well, with potentially positive results. It would place at the disposal of new and needy client populations labour law's vast experience with the mechanics of regulation, the promotion of collective action and the protection of individual rights. It could help a shrinking labour movement to form new alliances and to promote more widespread sympathy for its values and tactics. And merely reflecting on the idea might at a minimum help to reinvigorate labour law which, in the view of many, has become intellectually ossified.

Finally - most importantly for this occasion - the proposed reinvention of labour law might also transform its spatial dimension. I mean this in four senses. First, in many countries the contract of employment is conceptually, if not constitutionally, presumed to be a private and local matter. By subsuming employment relations into a more general category of "relations of economic subordination", the systemic — public, non-contractual — character of such relations becomes more apparent. Second, many countries long ago accepted that economic systems - markets - had become national rather than local in character, and ought therefore to be subject to national rather than local regulation. 
However, labour markets in some countries remained partially or entirely subject to subnational regulation. Conceivably the new characterization of employment relations as a sub-category of relations of economic subordination, as I have proposed, might allow or require those countries to ensure that any regime of labour regulation they construct is congruent with the markets it is intended to regulate. Third, it is now widely accepted that most markets operate across — rather than within — national borders and require some form of transnational regulation; an array of private and public transnational institutions structures business transactions, resolves disputes, protects intellectual property, facilitates capital transfers, and ensures the safe movement of goods, services and people. However, labour markets are treated somewhat differently. While the ILO plays an important role in setting and disseminating labour standards, their adoption and enforcement is left almost entirely to national or sub-national agencies. Global and regional trade regimes-including the EU — treat labour and employment issues far more diffidently than trade and business issues. And transnational corporations typically adhere to - even insist upon - the low labour standards that prevail in host countries where they produce or acquire goods, rather than use their leverage to export higher labour standards to those countries. Incorporating labour issues into a broader framework of developmental and trade concerns might gain them the same visibility that attaches, say, to environmental or health issues.

Finally, discursive global communities of professionals, academics, commentators and business operatives help to "normalize" and even intensify existing relations of 
subordination by demonstrating that they are not only inevitable but morally defensible. Greek pensioners, for example, deserve to suffer significant reductions in their standard of living because of their willingness to tolerate a political system characterized by corruption, tax evasion and fiscal irresponsibility; small-scale French businesses deserve to disappear because only the "creative destruction of capitalism" will liberate the economy from the inefficiencies they impose on it; and Canadian workers deserve to see their jobs shipped to Mexico or China because collective bargaining and the tax burdens of the welfare state have led to unsustainably high labour costs in the manufacturing sector. In this way, the discourses of market fundamentalism and global neo-liberalism legitimate a system of transnational governance in which the interests of subaltern groups - both labour and non-labour - receive little attention and less sympathy. So too do ideas of resistance. Acknowledgement of this "globalization of the mind" and its adverse effects on a wide variety of groups and individuals in many countries is a first step towards building an alternative governance model.

There is also some reason to believe that the spatial dimension of labour law can be enlarged. After all, advances in information technology have enabled workers in different countries to make contact and plan concerted action. Transnational social networks have mounted successful campaigns against the egregious abuse of workers' rights. Discursive communities of experts have been able to project worker-friendly models of labour market regulation across national boundaries and embed them in national legal systems. And arguably, Europe has begun to construct a system of social protection and labour regulation that in time may provide workers with guarantees that match or exceed those 
they enjoy under national laws. However, these are at best hopeful signs rather than persuasive evidence that progress has been achieved. Indeed, it would be hard to make a persuasive case that, overall, transnational economic integration has improved the lot of workers in the advanced economies rather than worsened it. In much of the developing world, it is true, a cohort of workers has gained access to jobs that pay decently, relative to local standards; but in general, they remain dreadfully exploited. Even in Europe, the development of community-wide norms has proven to be a two-edged sword. The Viking Laval and Ruffert cases threaten to move labour standards not upwards to a communitywide optimum, but downwards to the lowest common denominator.

\section{PART IV: $\quad$ TO THE PROMISED LAND? PROSPECTS FOR TRANSNATIONAL LABOUR REGULATION}

Like many labour lawyers, I believe that prospects for transnational labour regulation are dim, at least until the existential crisis of domestic or national labour law regimes has been resolved. However, unlike many of my colleagues in the field, I am at least prepared to contemplate the end of labour law as a distinct domain of scholarship and practice, and to at least imagine its absorption into the broader legal field that I have called "the law of economic subordination and resistance". I have suggested that this would require a shift in the intellectual ambition, clientele and spatial reach of labour law. Now, in conclusion, I suggest that it is just possible that the current global economic situation makes such a shift not only desirable, but somewhat more likely. 
The 2008 banking crisis caused by sub-prime mortgages and other unregulated financial derivatives demonstrated that national governments, entire economies and significant labour markets can be destabilized by the machinations or neglect of financial institutions doing business thousands of miles away. The more recent attempts to stave off the insolvency of several Euro-zone countries and American states and municipalities has been a dramatic reminder that international financial discipline entails unpleasant consequences not only for governments but potentially for all economic actors who depend on state contracts, employment, subsidy, regulation or macro-economic, taxation, industrial and trade policies — which is to say everyone.

We ought to be more alert than we used to be about the trans-systemic and transnational character of economic subordination, its deep, widespread and long-lasting effects, and the extent to which employment relations are typical of those effects rather than unique. However, we have not yet written our own Exodus, our compelling narrative of making bricks without straw in contemporary capitalism, not yet promulgated the ten commandments of decent economic relations in general and employment relations in particular, and not yet inscribed either of these in a "great code" that might shape the structures of our thought and the rhythms of our language.

David Trubek was not (so far as I know) found in the bulrushes nor has he parted any waters lately or lugged large stone tablets down a mountainside. But from his early work on law and development to his current work on transnational institutions, he has been constructing our narrative, prodding us to do a first draft of our ten commandments and 
developing a lexicon which will indeed have a lasting influence on how we all think and talk about regulation in an era of globalization. If we fail in our efforts to make regulatory bricks without the straw of state power, the fault will not be his. 